DOI: 10.4274/tod.galenos.2020.17136

Turk J Osteoporos 2020;26:1-5

\title{
Still a Major Concern: Osteoporosis Has a Serious Impact on Quality of Life
}

\author{
Hala Büyük Bir Kaygı: Osteoporoz Yaşam Kalitesi Üzerinde Ciddi Bir Etkiye Sahiptir \\ Yeşim Gökçe Kutsal \\ Hacettepe University Faculty of Medicine, Department of Physical Medicine and Rehabilitation, Ankara, Turkey
}

\section{Abstract}

Osteoporosis constitutes a major public health problem and health consequences from osteoporotic fractures in patients include disability having a negative impact on the quality of life. Physical, emotional, and psychological incapacity, combined with the pain that results from hip, spine, or wrist fractures, can alter quality of life. Even in the absence of fragility fractures osteoporotic patients have substantially lower quality of life scales. Quality of life in men and women with osteoporosis should be thoroughly investigated even prior to the occurrence of fracture, to develop appropriate interventions that would empower patients to effectively manage all stages of the disease. Also assessing quality of life is essential to health research and clinical trials involving osteoporosis. And the choice of the instrument used to assess quality of life depends on the type of research and on the research question asked; each instrument has specific advantages and disadvantages. The Quality of Life Questionnaire of the European Foundation for Osteoporosis and the Osteoporosis Quality of Life Questionnaire are targeted more toward fracture assessment, and the Osteoporosis Functional Disability Questionnaire can be used for longitudinal studies involving exercise. It is stated that, the huge burden caused by osteoporosis related fractures to individuals, healthcare systems and societies should provide a clear impetus for the progression of such approaches and assessment of quality of life seems to be an essential initial step.

Keywords: Osteoporosis, quality of life, questionnaire

\section{Öz}

Osteoporoz önemli bir halk sağlığı sorunudur ve osteoporotik kırıklara bağlı olarak gelişen sakatlıklar yaşam kalitesini olumsuz etkilemektedir. Fiziksel, duygusal ve psikolojik yeti kayıpları, kalça, omurga veya el bileği kırıklarından kaynaklanan ağrı ile birlikte yaşam kalitesini değiştirmektedir. Osteoporozlu erkeklerde ve kadınlarda, hastalı̆̆ın tüm aşamalarının etkili bir şekilde yönetilmesini sağlayacak uygun müdahaleler geliştirmek için, kırık oluşmadan önce bile yaşam kalitesi iyice araştırılmalıdır. Bilinmelidir ki; kırığı olmayan osteoporotic hastalarda bile yaşam kalitesi skorları düşük bulunmaktadır. Ayrıca yaşam kalitesini değerlendirmek, osteoporoz ile ilgili sağlık araştırmaları ve klinik çalışmalar için de gereklidir. Yaşam kalitesini değerlendirmek için kullanılan ölçeklerin seçimi araştırmanın türüne ve sorulan araştırma sorusuna bağlıdı; her ölçeğin kendine özgü avantajları ve dezavantajları vardır. Avrupa Osteoporoz Vakfı Yaşam Kalitesi Anketi ve Osteoporoz Yaşam Kalitesi Anketi daha çok kırık değerlendirmesini hedeflemektedir ve Osteoporoz Fonksiyonel Engellilik Anketi ise, egzersizi içeren uzunlamasına çalışmalar için kullanılabilir. Osteoporotik kırıkların gerek bireylere, gerekse sağlık sistemlerine ve toplumlara verdiği büyük yükün, bu tür yaklaşımların ilerletilmesi için açık bir itici güç olması gerektiği belirtilmekte olup, bu bağlamda yaşam kalitesinin değerlendirilmesi de önemli bir ilk adım özelliği taşımaktadır.

Anahtar kelimeler: Osteoporoz, yaşam kalitesi, anket

\section{Introduction}

\section{Major Public Health Problem}

Osteoporosis (OP) constitutes a major public health problem, through its association with age-related fractures, particularly of the hip, vertebrae, distal forearm and humerus. According to Curtis et al. (1), substantial geographic variation has been noted in the incidence of osteoporotic fractures worldwide, with Western populations, reporting increases in hip fracture throughout the second half of the 20th century, with a stabilization or decline in the last two decades. It is stated that, in developing populations however, particularly in Asia, the rates of osteoporotic fracture appears to be increasing. The massive global burden consequent to OP means that

Address for Correspondence/Yazışma Adresi: Yeşim Gökçe Kutsal MD, Hacettepe University Faculty of Medicine, Department of Physical Medicine and Rehabilitation, Ankara, Turkey

Phone: +90 3123051575 E-mail: ykutsal@hacettepe.edu.tr ORCID ID: orcid.org/0000-0003-3853-6452 Received/Geliş Tarihi: 16.02.2020 Accepted/Kabul Tarihi: 28.02.2020

${ }^{\circ}$ Copyright 2020 by the Turkish Osteoporosis Society / Turkish Journal of Osteoporosis published by Galenos Publishing House. 
fracture risk assessment should be a high priority among health measures considered by policy makers (1).

It is well known that; OP is a silent problem without any evidence of disease until a fracture occurs. Health consequences from osteoporotic fractures in patients include disability and have a negative impact on the Quality of Life (QoL) (2-4). The World Health Organization operational definition of $O P$, based on a measurement of bone mineral density (BMD) by dual-energy X-ray absorptiometry (DXA), has been used globally since the mid-1990s. However, although this definition identifies those at greatest individual risk of fracture, in the population overall a greater total number of fractures occur in individuals with BMD values above the threshold for OP diagnosis (1). It should be kept in mind that, OP should not be defined only as a loss of bone mass, because this entity is an important clinical syndrome, which causes many problems with respect to functional status and QoL. It is demonstrated that, patients who develop a vertebral compression fracture are at substantial risk for additional fractures and OP accounts for approximately half of all hip fractures and these fractures may cause chronic pain, disability, and death (2-4). If a vertebral fracture exists the focus shifts to rehabilitation and prevention of the next fracture (5). Currently more than 200 million people worldwide are estimated to be osteoporotic and it is predicted that; by 2050 there will be up to 21.3 million hip fractures each year globally (https://www.iofbonehealth.org/facts-statistics). Compared to other osteoporotic fractures, hip fractures require special attention given the high mortality risk associated.

\section{Risk Factors}

$\mathrm{OP}$ is a highly probable disease to be found when actively questioning patients within the age frame about signs or symptoms. However, when assessing OP and fracture risk, measurement of BMD will be required, that will complete the diagnosis and guide the management of the patient. Several international epidemiological surveys in different parts of the world have extensively analyzed the potential risk factors for OP and identified the following: age, smoking history, excessive alcohol consumption, low Body Mass index (BMI), low dietary calcium intake, vitamin D deficiency, little or no physical activity, visual impairment, frequent falls, female gender, premature menopause, amenorrhea, previous fragility fracture, a family history of hip fracture, low BMD, high bone turnover, neuromuscular disorders, longterm glucocorticoid therapy, and rheumatoid arthritis and being Asian or Caucasion was also determined to be a potential risk factor. In a cross-sectional, observational, multicenter study, a total of 730 postmenopausal women were assessed for risk factors associated with OP. The most frequent clinical risk factors for OP were inadequate sun exposure, current sedentary lifestyle, low calcium intake in adulthood and childhood, and sedentary lifestyle in adolescence. A total of 707 patients described more than one risk factor, while $74.3 \%$ of the patients reported one clinical risk factor at least for secondary OP (6). The authors stated that, adequate sun exposure and proper intake of dietary calcium beginning in childhood combined with lifelong daily physical activity may play a role in preventing OP in postmenopausal women. In addition, physicians should be aware of the high probability of secondary $\mathrm{OP}$ in this patient group (6).

A number of web-based tools to enable the inclusion of clinical risk factors, with or without BMD, in fracture prediction algorithms have been developed to improve the identification of individuals at high fracture risk, the most commonly used globally being FRAX®. Access to DXA, OP risk assessment, case finding and treatment varies worldwide, but despite such advances studies indicate that a minority of men and women at high fracture risk receive treatment (1).

\section{Fracture Prevention}

Reasons for suboptimal fracture prevention are: 1- Fractures do occur, mainly in the elderly, 2- Fear of severe side effects, 3- Lack of education in professionals and in the lay public, 4- Lack of engagement: OP is a low medical priority, 5- Lack of coordination between health care systems, 6Inadequate access to diagnostics such as BMD measurement and vertebral fracture assessment, 7- Suboptimal predictive value of diagnostic techniques, 8- The treatment gap, 9- Low adherence and compliance to anti-osteoporotic drugs, 10Generic drugs, nocebo-effect (negative counterpart), 11- Lack of focus on muscle strength and fall prevention (7).

As clearly stated bu Lems and Raterman, many other factors play a role, such as; to reach a high peak bone mass for the prevention of OP in young individuals, as well as the optimization of the use of imaging techniques (DXA and Vertebral Fracture Assesment and new techniques to measure the bone quality) and also the use of medical and nonmedical treatment options, and surgical techniques of fracture healing (8).

\section{Quality of Life}

Physical, emotional, and psychological incapacity, combined with the pain that results from hip, spine, or wrist fractures, can alter QoL. QoL in men and women with OP should be thoroughly investigated even prior to the occurrence of fracture, to develop appropriate interventions that would empower patients to effectively manage all stages of the disease (9). A sizeable body of literature has documented the detrimental effect of fragility fractures on the health-related QoL (HRQOL) of those with OP $(10,11)$.

\section{Assessment of QoL}

An important marker of the clinical evolution of patients with $\mathrm{OP}$ and fractures is assessment of health-related QoL. It should be kept in mind that, this assessment is central to health science research and clinical trials. Physical, emotional, and psychological incapacity, combined with the pain that results from hip, spine, 
or wrist fractures, can alter QoL. Several instruments, both generic and disease-specific, can be used to examine the QoL in OP and OP related fractures. Instruments assessing the QoL in general as well as disease-specific instruments have been developed (12-14)

According to Madureira et al. (15) nine specific questionnaires related to OP QoL are available in the literature. QUALEFO is the OP-specific questionnaire most commonly used in the literature. QUALEFFO and OQLQ are targeted more toward fracture assessments. OFDQ is used in longitudinal studies involving exercise. OP-specific QoL questionnaires should be validated in the language of the country of origin before being used. These specific questionnaires related to OP QoL were found to be: 1-The Women's Health Questionnaire, 2-OP Quality of Life Questionnaire, 3-OP Assessment Questionnaire,4-OP Functional Disability Questionnaire, 5-Quality of Life Questionnaire of the European Foundation for OP, 6-OP-Targeted Quality of Life Questionnaire, 7-Japanese OP Quality of Life Questionnaire, 8-The 16-item Assessment of Health-Related Quality of Life in OP, 9-The Quality of Life Questionnaire in OP (QUALIOSTTM). The Quality of Life Questionnaire of the European Foundation for OP is the OP-specific questionnaire most commonly used in the literature (15). The Quality of Life Questionnaire of the European Foundation for OP and the OP Quality of Life Questionnaire are targeted more toward fracture assessment, and the OP Functional Disability Questionnaire can be used for longitudinal studies involving exercise (15). Qualeffo-41 is a specially designed questionnaire approved by the International Association of OP for measuring the QoL in patients with postmenopausal OP. The questionnaire consists of 41 items and includes 5 domains: pain, physical function, social activities, general health perception and mental function (16).

Disease-specific scales have higher degrees of validity, when compared with general health-related scales with regard to format and content relevant to the disease of interest. Longevity of these forms, which take up much more time to complete, restricts their clinical usage. QUALEFFO was translated into Turkish and validation studies of the Turkish version of QUALEFFO in osteoporotic patients with vertebral fractures had been carried out. It consists of 41 questions and five domains. It takes about 10 minutes for the patient to complete (17). This questionnaire is validated for wrist fractures as well (18). Also a study was performed to develop a Turkish version of the mini OP Quality of Life Questionnaire (mini-OQLQ), and assess its reliability and validity. Validation study was assessed by correlating the scale with QUALEFFO 41. And the writers stated that; the Turkish version of the mini-OQLQ was found to be reliable and valid in the evaluation of life quality of patients with postmenopausal OP (19).

\section{Researches Based on The QoL}

Fracture history was shown to be associated with low QOL. The lowest scores are in femur and pelvis fractures in women, while in femur fractures in men. Researchers state that; distal forearm/wrist fractures affect the QoL least, while vertebral fractures are the ones that affect moderately, but those that affect the highest level are the hip fractures. While planning the treatment, not only the medical therapy, but also the patient's satisfaction and QoL should be taken into consideration as well $(20,21)$

The health related QoL in a population sample of postmenopausal women over the age of 50 was studied according to the presence/absence of OP and the severity of prevalent morphometric vertebral fractures. Eight hundred four postmenopausal women were assessed with the SF-12 questionnaire. Mild and moderate-severe vertebral fractures were associated with decreased scores in the SF-12 Physical Component Summary but not in the Mental Component Summary. Densitometric OP with no accompanying fracture was not associated with a worse health related QoL. After adjusting for confounding factors, the physical components of health related QoL were significantly lower in women with prevalent osteoporotic vertebral fractures than in women -osteoporotic or not- without vertebral fractures (22).

A cross-sectional analytic survey was conducted on 280

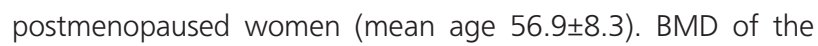
patients was diagnosed and OP-specific QoL criteria was used to determine the QoL. When the women's QoL compared with the results of DXA, a negative, moderate significant relationship was found. The QoL was decreasing in the individuals having older age and lower education level. The writers stated that, QoL of was higher in individuals having high income level, performing exercise and high activities (23). An another cross-sectional multicenter study was carried out among postmenopausal women with primary OP attending primary care centers and hospital outpatient clinics: 234 women with vertebral fractures and 244 asymptomatic women. All patients were questioned using the mini-OQLQ, Medical Outcomes Study Short Form36 (SF-36), and the EuroQuol-5D. Also Self-Administered Comorbidity Questionnaire was used to assess comorbidity. The vertebral fracture group had significantly lower scores than patients without fractures and controls in all domains of the generic and specific questionnaires. Women with only one prevalent fracture had statistically significantly lower HRQOL scores than those without fractures on SF-36 measures of bodily pain, physical functioning, and role function physical. HRQOL scores were lower in women with lumbar fractures compared with women with thoracic fractures only when the physical functioning and bodily pain dimensions approached statistical significance. The strongest determinant for low HRQOL was found to be the physical functioning (explained by number of vertebral fractures) followed by comorbidity score and age (24). The number of fractures was shown to be a determinant 
of a low QoL, as indicated by an increased score in physical function, social function, mental function, and general health all patients in a study conducted on Arabic women. Rostom et al. (25) found that; patients with higher grades of vertebral deformities, i.e., more severe fractures, had low QoL. Patients with thoracolumbar fractures had a worse general health than patients with thoracic or lumbar fractures. A high prevalence of vertebral fractures was probably explained by socioeconomic factors in Morocco. QoL, assessed by an OP-specific instrument, was found to be decreased in postmenopausal women as a function of both the number and the severity of the vertebral fractures.

\section{Effects of Physical Activity}

The effect of 24 weeks of aerobic dancing on the BMD, physical fitness and HRQoL in postmenopausal women with osteopenia were investigated (total 80 participants) in a study. The results suggested that, 24-week aerobic dance intervention could result in the lower the incidence of bone fracture through increasing BMD and decreasing fall risk for postmenopausal women. Grip strength, sidestep and physical functional domain of HRQoL in the exercise group were significantly improved compared to the contol group (26). Another single-blind randomized controlled prospective trial study (92 postmenopausal women) was consistent of 3 groups: First group of patients with exercises and physical modalities (gr. I), $2^{\text {nd }}$ group with exercises (gr. II) (practiced 3 times a week; each ex was repeated for 5-8 times. Third control group of patients who did not practice exercises (gr. III). Patients regularly took bisphosphonates, calcium and vitamin D. The follow-up period lasted for one year. QoL was determined with Qualeffo-41. According to the results, significant statistical difference in terms of pain, physical activity, social life, the perception of own health were shown between the groups only in term of mental function were no significant. Patients who practice exercises for OP had a significantly better QoL than patients who do not perform exercises (27).

\section{Absence of Fractures}

Association between HRQOL and OP in the absence of fracture was also evaluated $\geq 50$ years with 10-year follow-up (5266 women and 2112 men). Participants completed the SF-36, a detailed health questionnaire and measures of BMD at baseline and follow-up was performed. Women in the OP group had substantially lower SF-36 baseline scores, particularly in the physically oriented domains, than those without OP. A similar but attenuated pattern was evident for the men. After 10-year follow-up (2797 women and 1023 men) this study provided evidence of substantially reduced HRQOL in women and men with self-reported and/or BMD-confirmed OP, even in the absence of fragility fracture (9).

It is clearly seen that; assessing functional status and QoL has been considered central not only to evaluating disease progression, but developing treatments as well.

\section{Needs and Strategies}

There are a number of unmet needs when assessing OP and a number of strategies to prevent the continual increase of the disease. These are; 1- Optimizing peak bone mass in young adults, 2- Structural implementation of a four-step diagnostic procedure in patients with clinical risk factors for osteoporotic fractures: dual-energy DXA, vertebral fracture assessment, fall risk, secondary OP. 3- More adequate measurement of bone strength, 4- Reduction in the treatment gap, 5- New drugs with a better efficacy/safety profile, 6- Shared decision making with optimal nonmedical and medical treatment (Non pharmacological interventions include specific physical exercises for OP to improve muscle strength and balance, decrease pain, and improve QoL). 7- New strategies: treat to target and definition of high-risk patients (8). The cost of these fractures for societies is enormous and is forecast to steadily increase over the coming decades globally. Low BMD remains a key preventable risk factor for fractures. Screening and treatment of individuals with high risk of fracture is cost-effective. Predictive tools including "clinical risk factors", "minimization of falls risk" and "public authorities' support" to create Fracture Liaison Services are suggested as paramount strategies (28).

\section{Conclusion}

As a long-term chronic disease, OP and its complications have a considerable impact on patients' QoL, largely due to pain, restrictions on activity, and alterations in mood (3). It is stated that, the huge burden caused by OP related fractures to individuals, healthcare systems and societies should provide a clear impetus for the progression of such approaches (1). And assessing QoL is essential to health research and clinical trials involving OP. It should be taken into consideration that, the choice of the instrument used to assess QoL depends on the type of research and on the research question asked; each instrument has specific advantages and disadvantages. Another important issue is, these instruments should be available in the patient's native language and a specific methodology should have been established to validate their use $(15,29)$.

\section{Ethic}

Peer-review: Internally peer-reviewed.

Financial Disclosure: The author declared that this study received no financial support.

*This article is based (with the official permission of the editor) on the conference below: Kutsal Y G. Quality of life in osteoporosis. In: Eser E (Ed) International heath related quality of life meeting. Implementation of quality of life into clinical practice. Proceedings of 6 th International heath related quality of life meeting, İzmir, 2019 pp: 23-32 (ISBN: 978-605031-399-4). 


\section{References}

1. Curtis EM, Moon RJ, Harvey NC, Cooper C. The impact of fragility fracture and approaches to osteoporosis risk assessment worldwide. Bone 2017;104:29-38.

2. Cosman F, de Beur SJ, LeBoff MS, Lewiecki EM, Tanner B, Randall $S$, et al. Clinician's guide to prevention and treatment of osteoporosis. Osteoporos Int 2014;25:2359-81.

3. Badia $X$, Prieto $L$, Roset $M$, Diez-Perez A, Herdman $M$. Development of a short osteoporosis quality of life questionnaire by equating items from two existing instruments. Journal of Clinical Epidemiology 2002;55:32-40.

4. Pisani P, Renna MD, Conversano F, Casciaro E, Di Paola M, Quarta $E$, et al. Major osteoporotic fragility fractures: Risk factor updates and societal impact. World J Orthop. 2016;7:171-81.

5. Dionyssiotis $Y$. Management of osteoporotic vertebral fractures. Int J Gen Med 2010;3:167-71.

6. Gökçe Kutsal Y, Savaş S, İnanıcı F, Özdemir O, Karahan S, Doğan $A$, et al. The frequency of the clinical risk factors in postmenopausal osteoporosis. Arch Rheumatol 2013;28:256-62.

7. Ferrari S, Reginster JY, Brandi ML, Kanis JA, Devogelaer JP, Kaufman JM, et al. Unmet needs and current and future approaches for osteoporotic patients at high risk of hip fracture. Arch Osteoporos 2016;11:37.

8. Lems WF, Raterman HG. Critical issues and current challenges in osteoporosis and fracture prevention. An overview of unmet needs. Ther Adv Musculoskelet Dis. 2017;9:299-316.

9. Hopman WM, Berger C, Joseph L, Morin SN, Towheed T, Anastassiades $T$, et al. Longitudinal assessment of healthrelated quality of life in osteoporosis: data from the populationbased Canadian Multicentre Osteoporosis Study. Osteoporos Int 2019;30:1635-44.

10. Papaioannou A, Kennedy CC, Ioannidis G, Sawka A, Hopman WM, Pickard $L$, et al. The impact of incident fractures on health-related quality of life: 5 years of data from the Canadian multicentre osteoporosis study. Osteoporos Int 2009;20:703-14.

11. Guillemin F, Martinez L, Calvert M, Cooper C, Ganiats T, Gitlin $\mathrm{M}$, et al. Fear of falling, fracture history, and comorbidities are associated with health-related quality of life among European and US women with osteoporosis in a large international study. Osteoporos Int 2013;24:3001-10.

12. Lips $P$, van Schoor NM. Quality of life in patients with osteoporosis. Osteoporos Int 2005;16:447-55.

13. Peasgood T, Hermann K, Kanis JA, Brazier JE. An updated systematic review ofHealth State Utility Values for osteoporosis related conditions. Osteoporos Int 2009;20:853-68.

14. Thompson DR, Yu CM. Quality of life in patients with coronary heart disease-l: assessment tools. Health Qual Life Outcomes 2003;1:42.

15. Madureira MM, Ciconelli RM, RMR Pereira. Quality of life measurements in patients with osteoporosis and fractures. Clinics 2012;67:1315.
16. Van Schoor NM, Knol DL, Glas CA, Ostelo RW, Leplège A, Cooper C, et al. Development of the Qualeffo-31, an osteoporosis-specific quality-of-life questionnaire. Osteoporos Int 2006;17:543-51.

17. Koçyigit H, Gülseren S, Erol A, Hizli N, Memis A. The reliability and validity of the Turkish version of Quality of Life Questionnaire of the European Foundation for Osteoporosis (QUALEFFO). Clin Rheumatol 2003;22:18-23.

18. Lips P, Jameson K, Bianchi ML, Goemaere S, Boonen S, Reeve J, et al. Validation of the IOF quality of life questionnaire for patients with wrist fracture. Osteoporos Int 2010;21:61-70.

19. Yılmaz F, Fusun Sahin F, Doğu B, Ozmaden S, Kuran B. Reliability and validity of the Turkish version of the mini osteoporosis quality of life questionnaire. Journal of Back and Musculoskeletal Rehabilitation 2012;25:1-6.

20. Adachi JD, Loannidis G, Berger C, Joseph L, Papaioannou A, Pickard $L$, et al. The influence of osteoporotic fractures on healthrelated quality of life in community-dwelling men and women across Canada. Osteoporos Int 2001;12:903-8.

21. Adachi JD, loannidis G, Olszynski WP, Brown JP, Hanley DA, Sebaldt RJ, et al. The impact of incident vertebral and non-vertebral fractures on health related quality of life in postmenopausal women. BMC Musculoskelet Disord 2002;3:11.

22. Sanfélix-Genovés J, Hurtado I, Sanfélix-Gimeno G, Reig-Molla B, Peiró S. Impact of osteoporosis and vertebral fractures on qualityof-life. a population-based study in Valencia, Spain (The FRAVO Study). Health Qual Life Outcomes. 2011;9:20.

23. Pamuk G, Kutlu R, Çivi S. Evaluation of Quality of Life in Postmenopausal Women with and without Osteoporosis using the QUALEFFO-41 Scale. Turk J Phys Med Rehab 2014;60:139-46.

24. SalafŞF, Cimmino MA, Malavolta N, Carotti M, Di Matteo $L$, Scendoni $P$, et al. The burden of prevalent fractures on health-related quality of life in postmenopausal women with osteoporosis: the IMOF study. J Rheumatol 2007;34:1551-60.

25. Rostom S, Allali F, Bennani L, Abouqal R, Hajjaj-Hassouni N. The prevalence of vertebral fractures and health-related quality of life in postmenopausal women. Rheumatol Int 2012;32:971-80.

26. Yu PA, Hsu WH, Hsu WB, Kuo LT, Lin ZR, Shen WJ, et al. The effects of high impact exercise intervention on bone mineral density, physical fitness, and quality of life in postmenopausal women with osteopenia: A retrospective cohort study. Medicine (Baltimore) 2019;98:e14898.

27. Koevska V, Nikolikj-Dimitrova E, Mitrevska B, GjeracaroskaSavevska C, Gocevska M, Kalcovska B. Effect of Exercises on Quality of Life in Patients with Postmenopausal Osteoporosis Randomized Trial. Open Access Maced J Med Sci 2019;7:1160-5.

28. Sànchez-Riera L, Wilson N. Fragility Fractures \& Their Impact on Older People. Best Pract Res Clin Rheumatol 2017;31:169-91.

29. Morris RO, Masud T. Measuring quality of life in osteoporosis. Age Ageing 2001;30:371-3. 